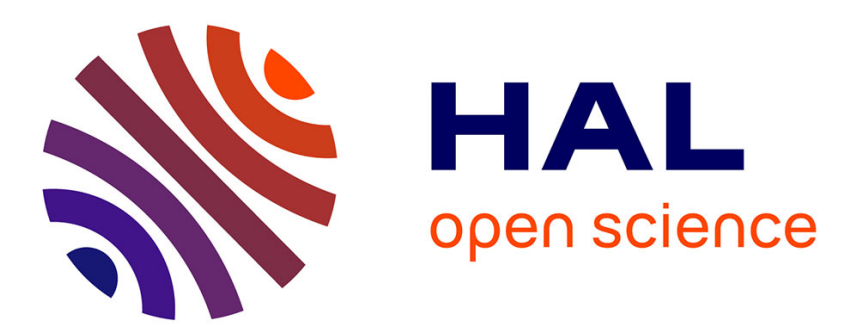

\title{
Erratum - Anomalous diffusion in random media of any dimensionality
}

\author{
J.P. Bouchaud, A. Comtet, A. Georges, P. Le Doussal
}

\section{To cite this version:}

J.P. Bouchaud, A. Comtet, A. Georges, P. Le Doussal. Erratum - Anomalous diffusion in random media of any dimensionality. Journal de Physique, 1988, 49 (2), pp.369-369. 10.1051/jphys:01988004902036900 . jpa-00210705

\section{HAL Id: jpa-00210705 https://hal.science/jpa-00210705}

Submitted on 1 Jan 1988

HAL is a multi-disciplinary open access archive for the deposit and dissemination of scientific research documents, whether they are published or not. The documents may come from teaching and research institutions in France or abroad, or from public or private research centers.
L'archive ouverte pluridisciplinaire HAL, est destinée au dépôt et à la diffusion de documents scientifiques de niveau recherche, publiés ou non, émanant des établissements d'enseignement et de recherche français ou étrangers, des laboratoires publics ou privés. 


\section{Erratum}

\section{Anomalous diffusion in random media of any dimensionality}

J. P. Bouchaud, A. Comtet, A. Georges and P. Le Doussal

(J. Phys. France 48 (1987) 1445)

We have found some mistakes in the published version of our paper quoted above :

(i) In the long-range correlated case $a<D$, the $\beta$-functions should read $(\varepsilon=2-a)$ :

$$
\begin{aligned}
& \beta_{\mathrm{T}}=-\varepsilon g_{\mathrm{T}}+8 C_{D}\left(1-\frac{1}{D}\right) g_{\mathrm{T}}^{2}+\cdots \\
& \beta_{\mathrm{L}}=-\varepsilon g_{\mathrm{L}}+8 C_{D}\left(1-\frac{1}{D}\right) g_{\mathrm{L}} g_{\mathrm{T}}+\cdots
\end{aligned}
$$

instead of equation (9), which holds for short-range correlations (with $\varepsilon=2-D, C_{D}=\frac{1}{2 \pi}$ ). This, however, does not modify the diffusion behaviours of table I, except for model I, where it becomes :

$$
\begin{array}{ll}
\text { for } a=2: t(\ln t)^{\frac{1}{2} \frac{D-2}{D-1}} & \text { instead of } t(\ln t)^{\frac{D-2}{D-1}} \\
\text { for } a<2: t^{1+\frac{D-2}{D-1} \frac{\varepsilon}{4}} & \text { instead of } t^{1+\frac{D-2}{D-1} \frac{\varepsilon}{2}}
\end{array}
$$

For a general situation however, with an arbitrary ratio $g_{\mathrm{T}} / g_{\mathrm{L}}$, the structure of the RG flow is modified (in the long-ranged case), resulting (at one loop order) in a diffusion exponent depending continuously on this ratio.

(ii) In the potential case (model III), since we have shown that the corrections to the $\beta$-function vanish at all orders, the result given in table $\mathrm{I}$ in the marginal case $a=2$ can in fact be generalized at arbitrary disorder under the following form (apart from possible non-perturbative effects) :

$$
\overline{X^{2}(t)} \sim t^{2 \nu} \quad \text { with } \quad 2 \nu=\left[1+2 \frac{C_{D}}{D} \sigma\right]^{-1}
$$

$\nu$ thus depends continuously on the strength of the disorder $\sigma$, defined by: $G_{\mathrm{L}}(k) \sim 4 \sigma k^{a-D}$ where $G_{\mathrm{L}}$ is defined by equations $(2,3)$. 